\title{
ANALISIS PENGARUH PENGGUNAAN COLUMN HEAD PADA SISTEM FLAT SLAB DENGAN DROP PANEL
}

\author{
Damai Reformasi Gea ${ }^{1}$ dan Edison Leo ${ }^{2}$ \\ ${ }^{1}$ Program Studi Sarjana Teknik Sipil, Universitas Tarumanagara, Jl. Letjen S. Parman No. 1 Jakarta \\ Email : Dreformasigea@gmail.com \\ ${ }^{2}$ Program Studi Sarjana Teknik Sipil, Universitas Tarumanagara, Jl. Letjen S. Parman No. 1 Jakarta \\ Email : edisonl@ft.untar.ac.id
}

\begin{abstract}
ABSTRAK
Proyek konstruksi dewasa ini mengalami banyak perkembangan yang membuat setiap pekerja proyek berbondong-bondong melakukan inovasi. Salah satu inovasi terkini pada proyek kontruksi terdapat pada perancangan pelat lantai. Pada mulanya perancangan pelat lantai di desain dengan metode konvensional dimana metode ini membutuhkan biaya dan waktu yang tinggi. Sehingga para pekerja konstruksi berinovasi untuk merancang sebuah pelat tanpa memakan banyak biaya dan waktu. Hasil inovasi itu ditemukan salah satu metode perancangan pelat yang sering disebut flat slab.Tujuan dari penelitian ini ialah melihat pengaruh geser dan momen pada flat slab jika kita menggunakan drop panel dan column head pada kolom. Analisis ini menggunakan metode pendekatan pelat dan metode elemen hingga. Dimana pendekatan Pelat menggunakan metode portal ekivalen.
\end{abstract}

Kata Kunci : Drop Panel, Column Head, Flat Slab dan Geser Pons

\section{PENDAHULUAN}

\section{Latar Belakang}

Kemajuan teknologi pada zaman ini sangat cepat dan mempengaruhi berbagai sektor dalam kehidupan manusia, termasuk salah satunya dalam bidang konstruksi. Pada dunia konstruksi pun mengalami perkembang seiring dengan kemajuan zaman dan teknologi, termasuk dalam konstruksi pelat lantai (slab), yang mulanya hanya dikenal konstruksi pelat konvensional (conventional slab). Sedangkan menurut SNI 2847:2013 ada pelat jenis lain selain pelat konvensional, yaitu pelat cendawan (flat slab), rib slab dan waffle slab. Pada pembahasan kali ini akan dibahas besarnya momen lentur dan geser pons yang terjadi pada flat slab dengan kondisi membandingkan penggunaan drop panel dan column head. dengan lebar column head yang bervariasi. Dimana drop panel itu sendiri ialah penebalan yang dilakukan dibawah pelat yang berfungsi untuk mengurangi terjadinya geser pons (punching shear) yang terjadi pada pelat akibat gaya atau beban yang bekerja langsung pada kolom sehingga menekan pelat dan juga mengurangi jumlah tulangan negatif di kolom sehingga memperkecil momen negatif yang terjadi, ada pun drop panel memiliki syarat lebar dan tebal maksimum berdasarkan SNI, sehingga karena syarat tersebut terkadang terjadi geser pons dan momen lentur yang tidak bisa ditahan atau dipikul oleh drop panel maka biasanya digunakan column head untuk membantu drop panel dan kolom dalam menahan gaya geser pons dan momen pada pelat, dimana column head ini sendiri memiliki batas lebar sudut yang sudah di tentukan pada ACI (American concrete institute) sebesar $90^{\circ}$, oleh sebab itu disini akan di analisis penggunaan column head dengan variasi sudut yang berbeda-beda untuk melihat pengaruh bagaimana jika dianalisis dengan ukuran sudut column head lebih kecil dari $90^{\circ}$ atau lebih besar dari $90^{\circ}$ dan sama dengan $90^{\circ}$. Analisis juga akan dilakukan dengan membandingkan hasil perhitungan SNI dengan hasil analisis metode elemen hingga.

\section{Tujuan}

Tujuan dari penelitian ini adalah untuk mengetahui pengaruh penggunaan column head pada momen dan geser pons, dimana analisis dilakukan dengan metode elemen hingga dibantu software dan analisis teoritis dengan SNI. 


\section{Batasan Masalah}

Batasan masalah pada penelitian ini adalah analisis numerik dilakukan dengan Metode Elemen Hingga menggunakan program berbasis Finite Element Analysis (FEA), studi difokuskan pada momen lentur dan geser pons pada saat kondisi adanya drop panel dan kondisi adanya column head, tulangan tidak dimodelkan dalam struktur hanya betonnya saja, Panel pelat lantai yang digunakan berukuran 20m x 20m, dengan jarak antar kolom adalah simetris 5m, Ketebalan flat slab diambil 150mm, Drop panel diambil berbentuk persegi dengan ukuran 2000mm x 2000mm dengan ketebalan yaitu 150mm, Ukuran kolom digunakan 400mm x 400mm, Lebar Column head berdasarkan sudut $120^{\circ}$, $90^{\circ}$ dan $60^{\circ}$ dan tebal $700 \mathrm{~mm}$, dan Perletakan kolom digunakan jepit.

\section{TINJAUAN PUSTAKA}

\section{Metode Portal Ekivalen}

Struktur harus dianggap terbuat dari rangka-rangka ekivalen pada garis-garis kolom yang diambil secara memanjang dan melintang melewati bangunan. Setiap rangka harus terdiri dari sebaris kolom atau pendukung dan lajur slab-balok, yang dibatasi secara lateral oleh garis pusat panel pada setiap sisi garis pusat kolom atau tumpuan. Kolom atau pendukung harus diasumsikan terhubung dengan lajur slab-balok oleh komponen struktur punter transversal terhadap arah bentang dimana momen ditentukan dan menerus hingga garis-garis pusat panel lateral pembatas pada setiap sisi kolom. Rangka yang bersebelahan dan sejajar terhadap suatu tepi harus dibatasi oleh tepi tersebut dan garis pusat panel yang bersebelahan. Analisis setiap rangka ekivalen secara keseluruhan diizinkan. Sebagai alternative, untuk pembebanan gravitasi, analisis setiap lantai atau atap secara terpisah dengan ujung-ujung jauh kolom dianggap terjepit diizinkan. Bila slab-balok dianalisis secara terpisah, penentuan momen pada suatu tumpuan dengan mengasumsikan bahwa slab-balok terjepit pada sebarang tumpuan dua panel yang terpisah darinya, diizinkan, asalkan slab tersebut menerus melewati titik tersebut.

\section{Geser Pons Flat Slab}

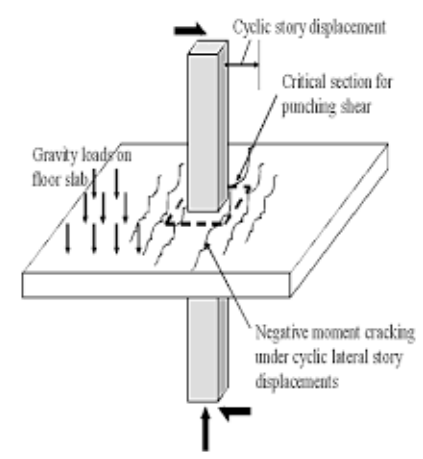

Gambar 1 Keruntuhan Geser Pons

Perhitungan geser pons pada flat slab dapat dihitung menggunakan rumus:

$$
\sigma_{\mathrm{U}}=\frac{\mathrm{v}_{\mathrm{U}}}{\mathrm{b}_{0} \cdot \mathrm{d}}+\frac{\gamma_{2} \cdot \mathrm{M}_{2} \cdot \mathrm{c}_{\mathrm{AB}}}{\mathrm{J}_{2}}+\frac{\gamma_{3} \mathrm{M}_{3} \cdot \mathrm{c}_{\mathrm{CD}}}{\mathrm{J}_{3}}
$$

Keterangan $\sigma_{\mathrm{U}}=$ tegangan geser pons $(\mathrm{MPa})$

$$
\begin{aligned}
& \mathrm{Vu}=\text { gaya geser }(\mathrm{N}) \\
& \mathrm{d}=\text { tebal pelat efektif }(\mathrm{mm}) \\
& \mathrm{bo}=\text { keliling critical section }(\mathrm{mm}) \\
& \gamma_{2}=1-\gamma_{\mathrm{v}} \\
& \gamma_{\mathrm{v}}=1-\frac{1}{1+\frac{2}{3} \sqrt{\frac{b_{1}}{b_{2}}}} \\
& \mathrm{M} 2=\text { momen pada pelat akibat eksentrisitas }(\mathrm{Nmm})
\end{aligned}
$$


$\mathrm{cAB}=$ jarak titik geser ujung ke titik geser pusat $(\mathrm{mm})$

$\mathrm{J} 2=$ momen inersia critical section $\left(\mathrm{mm}^{4}\right)$

\section{Kuat Geser pada Pelat}

Kuat Geser Nominal Beton, Vc Desain pelat dua arah terhadap geser pons berdasarkan peraturan SNI, ditentukan Vc harus diambil terkecil dari (1), (2), dan (3):

$V c=0,33 \lambda \sqrt{ } f c^{\prime}$ bod, dengan $\lambda$ adalah factor untuk jenis beton ringan (beton biasa digunakan $\lambda=1$ ), fc'adalah mutu beton, dan d adalah tebal efektif pelat.

$V c=0,083(\alpha s d b 0+2) \lambda \sqrt{ } f c^{\prime} b 0 d$, dimana $\alpha$ s adalah 40 untuk kolom interior, 30 untuk kolom tepi, dan 20 untuk kolom eksterior.

$V c=0,17(1+2 \beta) \lambda \sqrt{ } f c^{\prime} b 0 d$, dengan $\beta$ adalah rasio sisi terpanjang dan terpendek kolom, beban terpusat, atau daerah reaksi.

\section{METODE PENELITIAN}

Pada penelitian ini akan dilakukan perbandingan antara hasil analisis secara teori yang menggunakan metode portal ekivalen dengan hasil analisis dengan menggunakan software berbasis elemen hingga. Dimana analisis ini dilakukan hanya melihat seberapa besar pengaruh penggunaan column head terhadap geser pons dan momen yang terjadi, serta melihat seberapa besar perbedaan hasil yang didapatkan dari analisis secara teori maupun analisis dengan bantuan software. Analisis ini memerlukan data-data spesifikasi perancangan struktur. Setelah spesifikasinya ditentukan maka analisis pun dapat dilakukan, baik secara teoritis maupun batuan software.

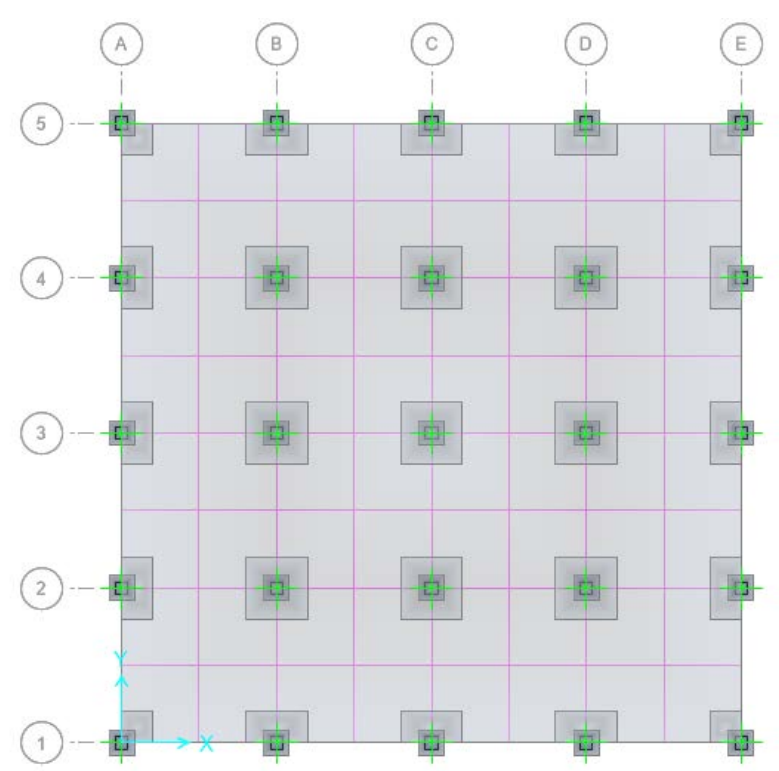

Gambar 2 Denah Struktur Flat Slab 


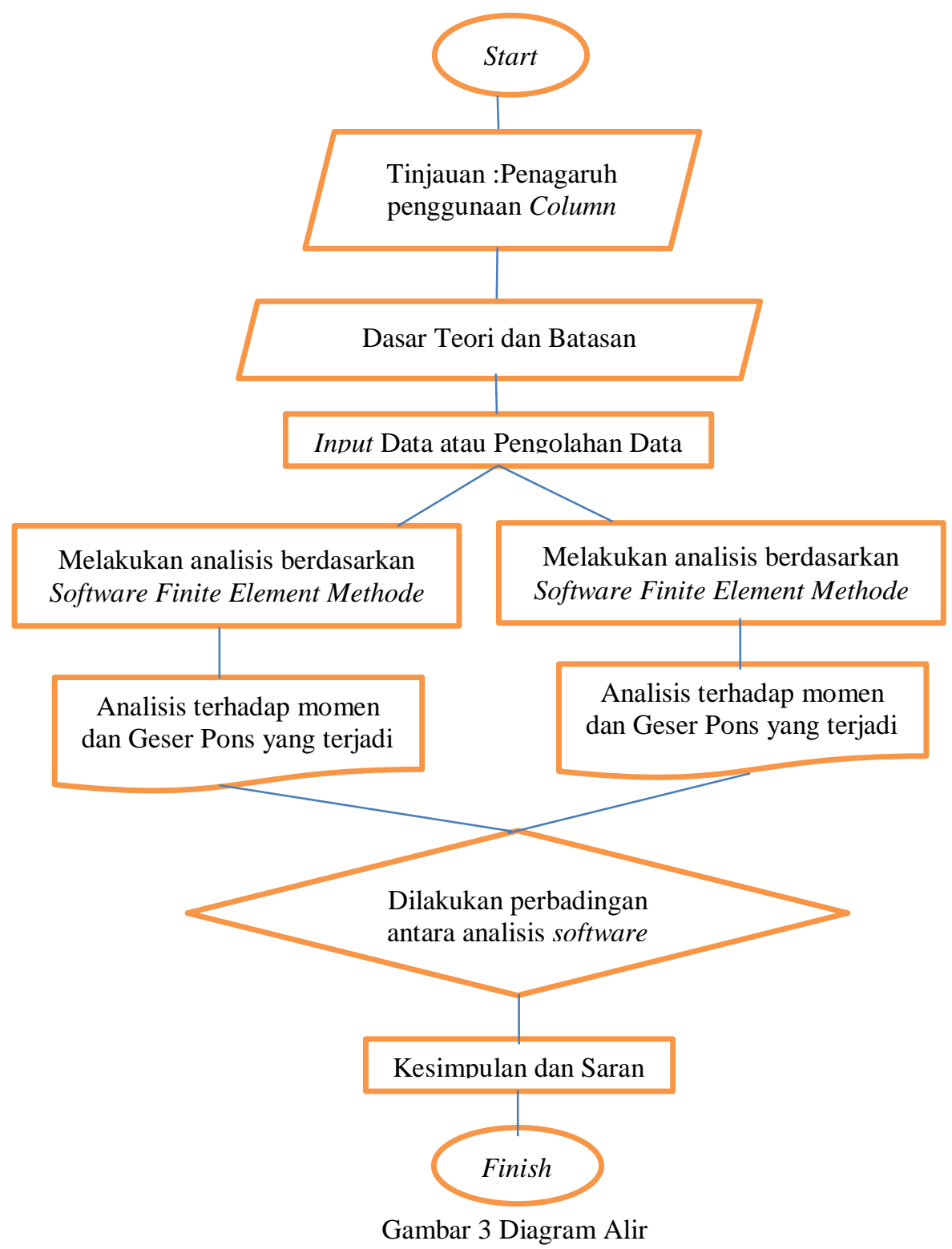

\section{HASIL DAN PEMBAHASAN}

Data :

Jarak antar kolom (11/ 12)

Jarak bersih muka kolom $(\ln 1 / \ln 2)$

$=6 \mathrm{~m}$

Tebal pelat

$=5,5 \mathrm{~m}$

DL

$=150 \mathrm{~mm}$

$=0,15 \mathrm{~m} \mathrm{x} 24 \mathrm{kN} / \mathrm{m} 3$

SDL

$=3,6 \mathrm{kN} / \mathrm{m} 2$

LL

$=1.5 \mathrm{kN} / \mathrm{m} 2$

Ultimate Load (qu)

$=4.79 \mathrm{kN} / \mathrm{m} 2$

= 1,2 DL + 1,6 LL

f'c flat slab \& drop panel

$=11,92 \mathrm{kN} / \mathrm{m} 2$

$=30 \mathrm{MPa}$ 


$\begin{array}{ll}\text { f'c kolom } & =40 \mathrm{MPa} \\ \text { Kolom } & =400 \mathrm{~mm} \text { x } 400 \mathrm{~mm} \\ \text { Ketebalan column head } & =700 \mathrm{~mm} \\ \text { Drop panel } & =2000 \mathrm{~mm} \times 2000 \mathrm{~mm} \\ \text { Ketebalan drop panel } & =150 \mathrm{~mm} \\ \text { Berat jenis beton } & =24 \mathrm{kN} / \mathrm{m} 3\end{array}$

Analisis yang akan dilakukan dengan beberapa model yitu:

- Model 1= Dengan Drop Panel 150mm

- Model 2= Dengan Column head 60 dan Drop Panel 150mm

- Model 3= Dengan Column head 90 dan Drop Panel 150mm

- Model 4= Dengan Column head $110^{\circ}$ dan Drop Panel 150mm

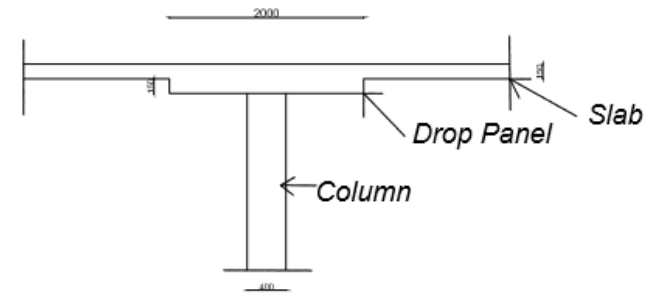

Gambar 3 Model 1

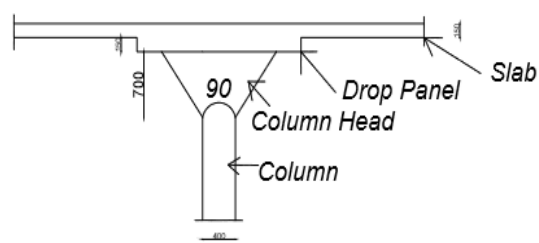

Gambar 5 Model 3

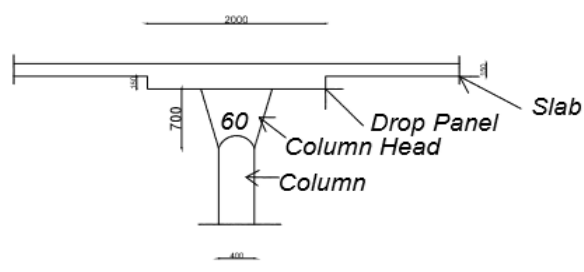

Gambar 4 Model 2

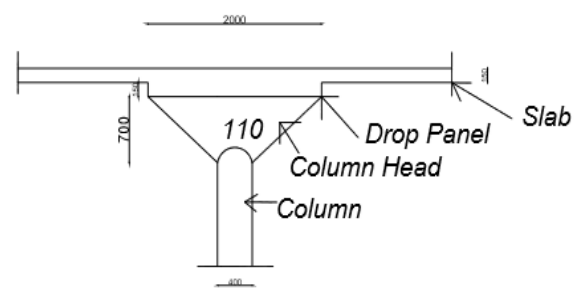

Gambar 6 Model 4

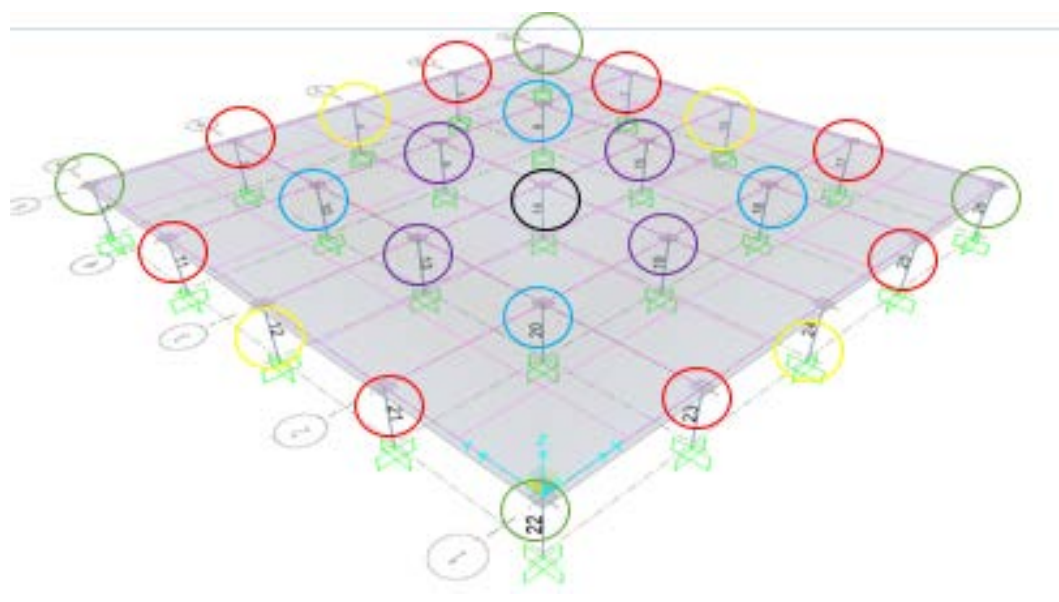

Gambar 7 Penamaan Letak Geser Pons 
Untuk penamaan kolom pada geser pons adalah sebagai berikut.

- $\quad$ Kolom Tipe I

$=$ Kolom 1,6,22,26

- $\quad$ Kolom Tipe II

$=\quad$ Kolom 3,5,7,17,25,23,11,21

$=\quad$ Kolom 12,4,16,24

- $\quad$ Kolom Tipe IV

$=\quad$ Kolom 8,10,18,20

- $\quad$ Kolom Tipe V

$=\quad$ Kolom 13,9,15,19

- Kolom Tipe VI = Kolom 14

\section{Hasil Finite Element Analysis (FEA)}

Berdasarkan hasil perhitungan finite element didapatkan hasil sebagai berikut :

Dari FEA didapatkan besar momen lentur dan geser pons kolom tipe 1 sebagai berikut.

Tabel 1 Rasio Tegangan Geser Pons/ Tegangan Tahanan Geser pada Kolom Tipe 1

\begin{tabular}{|c|c|c|}
\hline No & Tipe Struktur & Rasio Tegangan Geser Pons/ Tegangan Tahanan Geser \\
\hline 1 & Drop Panel & 1,331414 \\
\hline 2 & $\begin{array}{c}\text { Column Head } \\
60\end{array}$ & 1,049137 \\
\hline 3 & $\begin{array}{c}\text { Column Head } \\
90\end{array}$ & 0,429709 \\
\hline 4 & $\begin{array}{c}\text { Column Head } \\
110\end{array}$ & 0,267421 \\
\hline
\end{tabular}

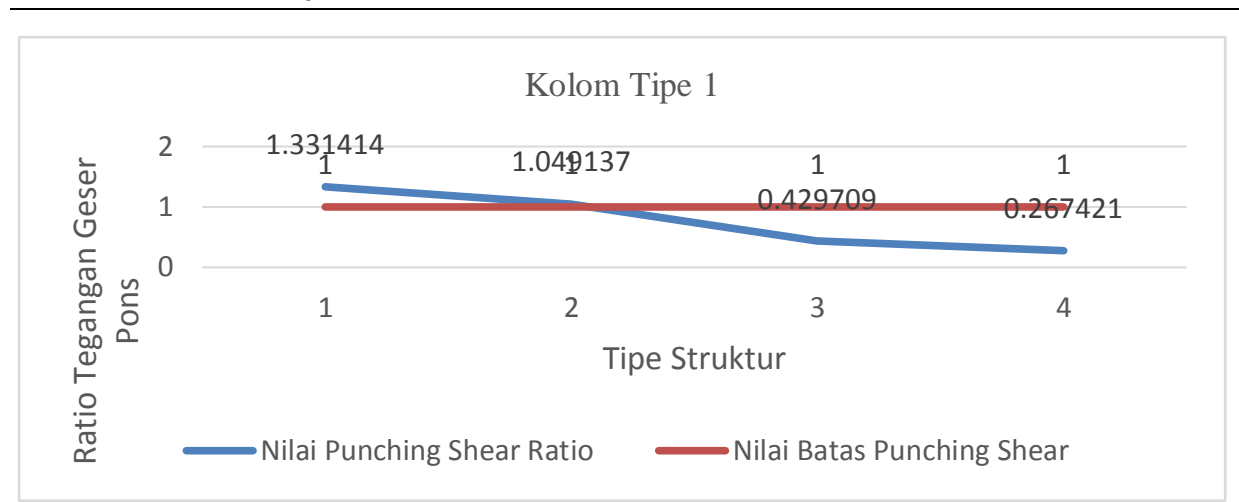

Gambar 8Grafik Penurunan Rasio Tegangan Geser Pons/ Tegangan Tahanan Geser pada Kolom Tipe 1

Dari FEA didapatkan besar momen lentur dan geser pons kolom tipe 2 sebagai berikut.

Tabel 2 Rasio Tegangan Geser Pons/ Tegangan Tahanan Geser pada Kolom Tipe 2

\begin{tabular}{ccc}
\hline No & Tipe Struktur & Rasio Tegangan Geser Pons/ Tegangan Tahanan Geser \\
\hline 1 & Drop Panel & 1,415934 \\
\hline 2 & $\begin{array}{c}\text { Column Head } \\
60\end{array}$ & 0,761777 \\
\hline 3 & $\begin{array}{c}\text { Column Head } \\
90\end{array}$ & 0,399525 \\
\hline 4 & $\begin{array}{c}\text { Column Head } \\
110\end{array}$ & 0,422758 \\
\hline
\end{tabular}




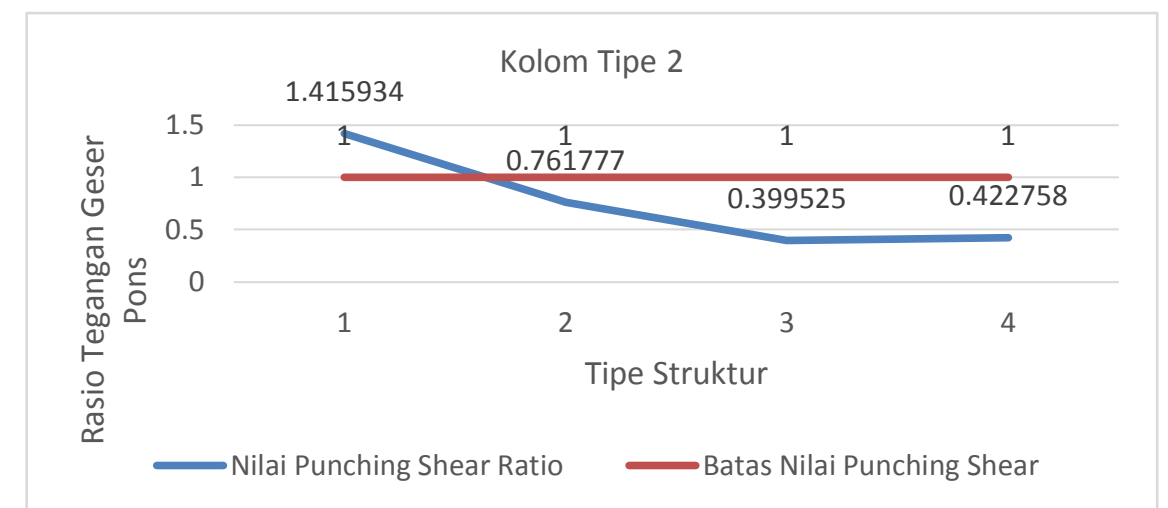

Gambar 9 Grafik Penurunan Rasio Tegangan Geser Pons/ Tegangan Tahanan Geser pada Kolom Tipe 2

Dari FEA didapatkan besar momen lentur dan geser pons kolom tipe 3 sebagai berikut.

Tabel 3 Rasio Tegangan Geser Pons/ Tegangan Tahanan Geser pada Kolom Tipe 3

\begin{tabular}{|c|c|c|}
\hline No & Tipe Struktur & $\begin{array}{c}\text { Rasio Tegangan Geser Pons/ Tegangan Tahanan } \\
\text { Geser }\end{array}$ \\
\hline 1 & Drop Panel & 1,325502 \\
\hline 2 & $\begin{array}{l}\text { Column Head } \\
60\end{array}$ & 0,699072 \\
\hline 3 & $\begin{array}{l}\text { Column Head } \\
90\end{array}$ & 0,364282 \\
\hline 4 & $\begin{array}{l}\text { Column Head } \\
110\end{array}$ & 0,371436 \\
\hline
\end{tabular}

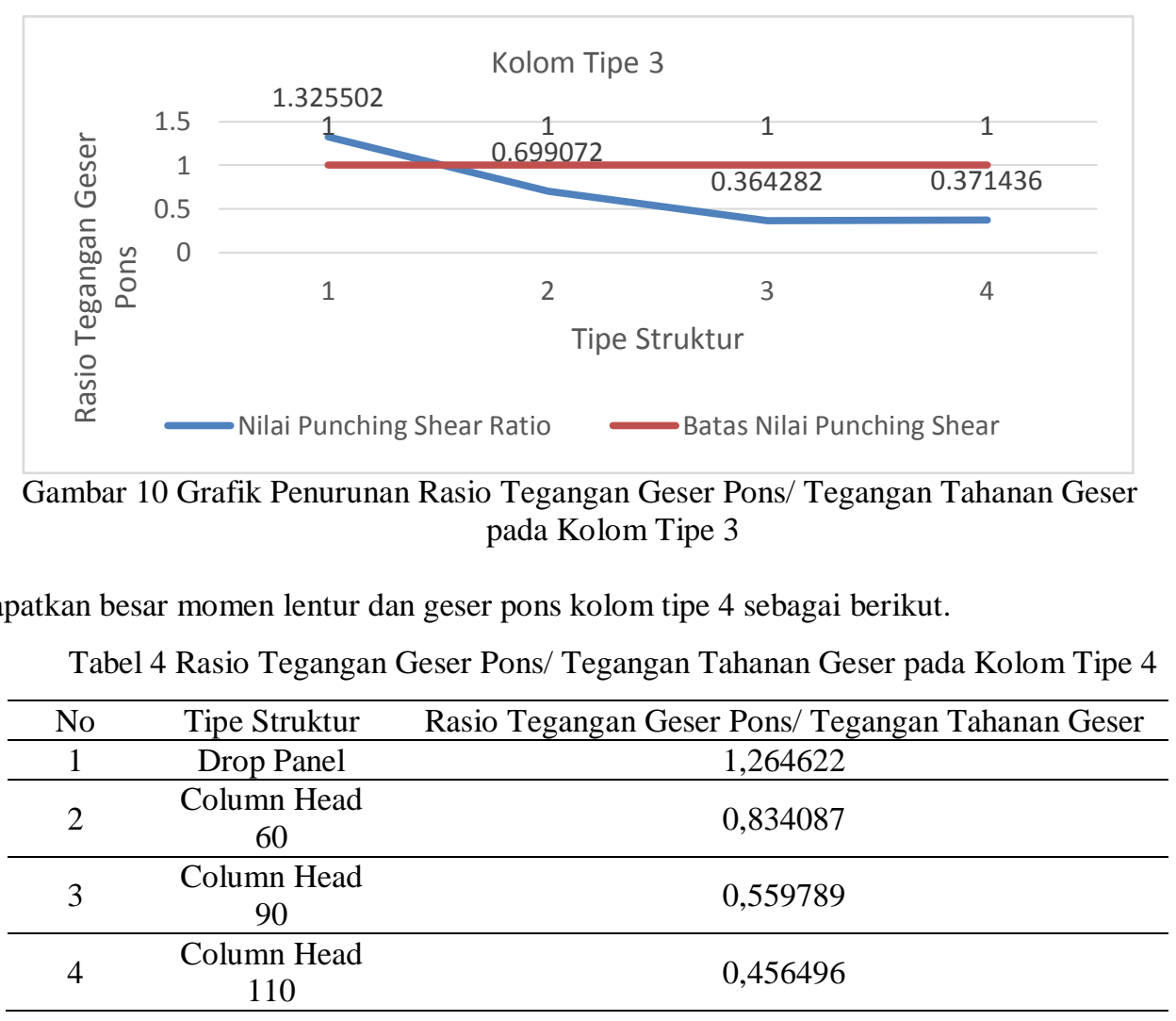




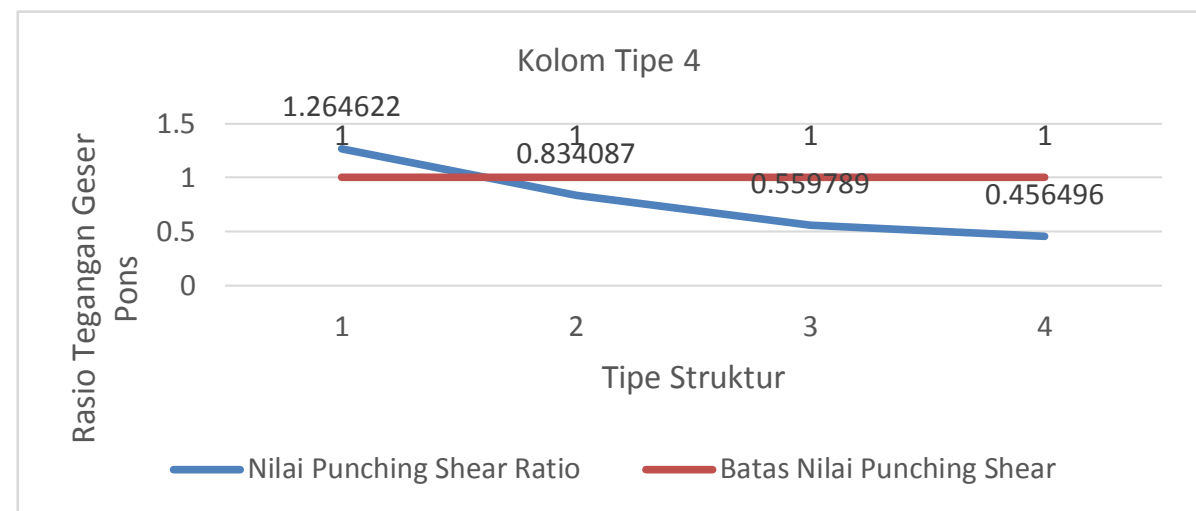

Gambar 11 Grafik Penurunan Rasio Tegangan Geser Pons/ Tegangan Tahanan Geser pada Kolom Tipe 4

Dari FEA didapatkan besar momen lentur dan geser pons kolom tipe 5 sebagai berikut.

Tabel 5 Rasio Tegangan Geser Pons/ Tegangan Tahanan Geser pada Kolom Tipe 5

\begin{tabular}{ccc}
\hline No & Tipe Struktur & Rasio Tegangan Geser Pons/ Tegangan Tahanan Geser \\
\hline 1 & Drop Panel & 1,139461 \\
\hline 2 & $\begin{array}{c}\text { Column Head } \\
60\end{array}$ & 0,749363 \\
\hline 3 & $\begin{array}{c}\text { Column Head } \\
90\end{array}$ & 0,500505 \\
\hline 4 & Column Head & 0,404071 \\
\hline
\end{tabular}

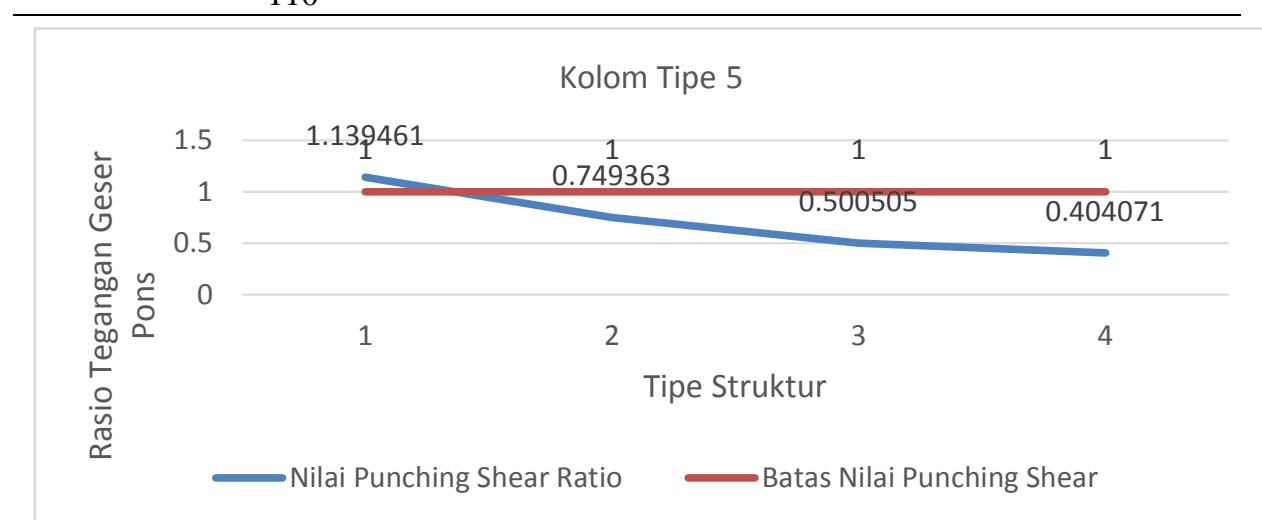

Gambar 12 Grafik Penurunan Rasio Tegangan Geser Pons/ Tegangan Tahanan Geser pada Kolom Tipe 5

Dari FEA didapatkan besar momen lentur dan geser pons kolom tipe 6 sebagai berikut.

Tabel 6 Rasio Tegangan Geser Pons/ Tegangan Tahanan Geser pada Kolom Tipe 6

\begin{tabular}{ccc}
\hline No & Tipe Struktur & Rasio Tegangan Geser Pons/ Tegangan Tahanan Geser \\
\hline 1 & Drop Panel & 0.950543 \\
\hline 2 & Column Head 60 & 0,659953 \\
\hline 3 & Column Head 90 & 0,437466 \\
\hline 4 & Column Head & 0,348738 \\
\hline
\end{tabular}




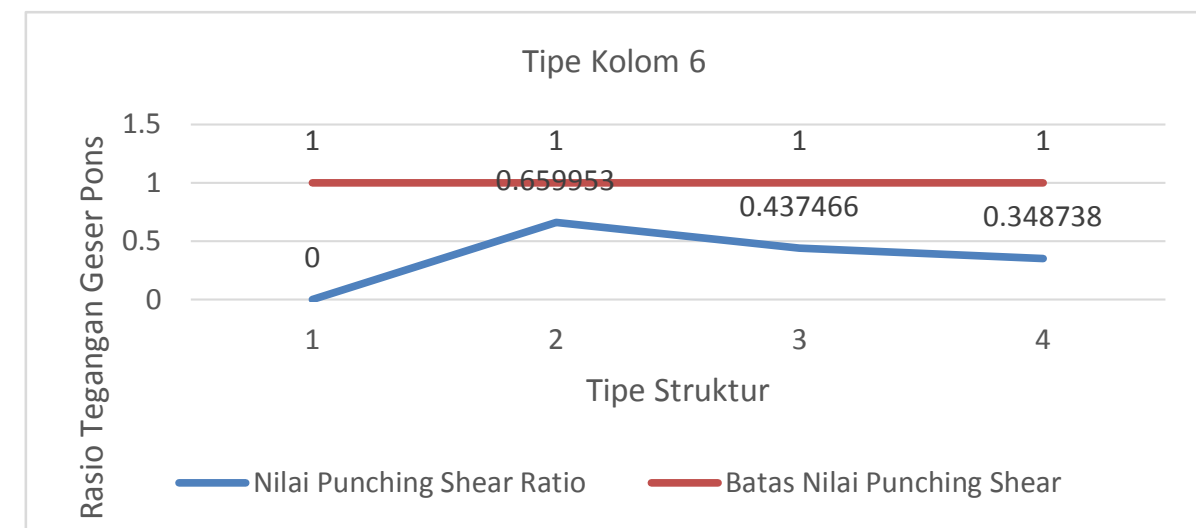

Gambar 13 Grafik Penurunan Rasio Tegangan Geser Pons/ Tegangan Tahanan Geser pada Kolom Tipe 6

Dari FEA didapatkan perbedaan perubahan momen sebagai berikut.

Tabel 7 Perbandingan Nilai Momen pada Tumpuan Span 1

\begin{tabular}{ccc}
\hline No & Tipe Struktur & Momen pada Tumpuan 1 \\
\hline 1 & Column head & $-6,5557$ \\
\hline 2 & Column head 90 & $-16,1566$ \\
\hline 3 & Column head 60 & $-34,2105$ \\
\hline 4 & Drop Panel & $-52,202$ \\
\hline
\end{tabular}

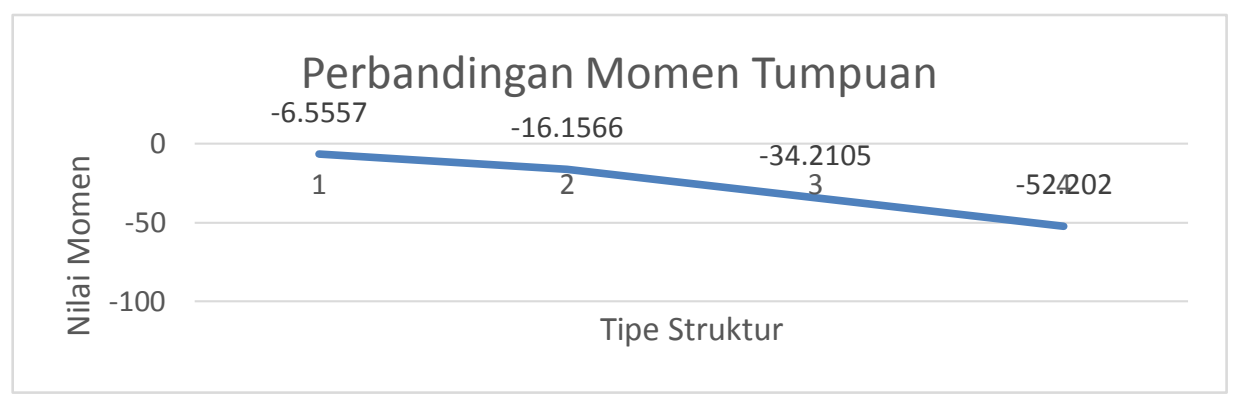

Gambar 14 Grafik Penurunan Nilai Momen pada Tumpuan Span 1

Dari grafik dan tabel diatas dapat dilihat bahwa nilai momen yang terjadi pada tumpuan semakin mengecil.

\section{KESIMPULAN DAN SARAN}

\section{Kesimpulan}

Dari hasil analisis yang sudah dilakukan dapat ditarik kesimpulan sebagai berikut:

1. Column head mereduksi tegangan geser pons pada struktur. Hanya saja besarnya reduksi yang didapatkan bergantung dari dimensi column head. Dimana Semakin lebar sudut column head yang digunakan maka semakin kecil juga nilai geser pons yang didapatkan, sehinnga dari hasil analisis dapat dilihat bahwa lebar sudut Column head yang efektif adalah sudut $90^{\circ}$, sebab penurunan yang terjadi sangat signifikan

2. Penambahan Column head dapat memperkecil nilai momen yang terjadi baik pada lapangan maupun pada tumpuan. 


\section{Saran}

Dari hasil analisis yang dilakukan didapatkan beberapa hal yang cukup signifikan perbedaannya dan kesulitannya, maka dari itu penulis menyarankan sebagai berikut:

1. Untuk penelitian selanjutnya dapat dicoba untuk memperhitungkan gaya gempa/gaya lateral yang terjadi.

2. Dapat dicoba dengan bentang yang cukup Panjang untuk melihat pengaruh column head terhadap panjang bentang.

3. Perhitungan teoritis dapat dicoba dengan teori lain, sebab teori pendekatan kurang baik atau efisien jika digunakan pada perhitungan ini.

\section{DAFTAR PUSTAKA}

ACI Committe 213R-79. (1979). “Guide for Structural Lightweight Aggregate Concrete”, ACI Manual of Concrete Practice.

Chavan, G. R. dan Tande, S. N. (2016). “Analysis and Design of Flat Slab”. International Journal of Latest Trends in Engineering and Technology.

Gregor, J.G.M., (1997), Reinforced Concrete Mechanics and Designs, Third Edition. Prentice Hall, Inc. Upper Saddle River, New Jersey.

R.S.More ${ }^{1}$, V. S. Sawant ${ }^{2}$, Y. R. Suryawanshi ${ }^{3}$ (2013). “Analytical Study of Different Types of Flat Slab Subjected to Dynamic Loading”. India.

SNI 2847, (2013). “Persyaratan Beton Struktural Untuk Bangunan Gedung”. Jakarta.

Tilva, V.K. (2016). “Cost Comparison Between Flat Slab with Drop and Without Drop in Four Storey Lateral Load Resisting Building”. National Conference on Recent Trends in Engineering \& Technology. 